\title{
Implementasi Teori Penetrasi Sosial pada Pengguna Aplikasi Tinder
}

\author{
Alvin Gus Abdurrahman ${ }^{1}$, Chairun Nisa Dwi Putri ${ }^{2}$, Irwansyah ${ }^{3}$ \\ 1,2,3 Pasca Sarjana Departemen Ilmu Komunikasi Universitas Indonesia \\ J1. Salemba Raya No 4, Jakarta Pusat, DKI Jakarta, 10430, Indonesia \\ Email: ${ }^{1}$ alvin.gus01@ui.ac.id, ${ }^{2}$ chairun.nisa01@ui.ac.id, ${ }^{3}$ irwansyah09@ui.ac.id
}

Received: June 2021; Accepted: October 2021; Published: December 2021

\begin{abstract}
The Covid-19 pandemic has changed social behaviour in society. Especially in the process of building relationships with opposite sex, which is usually done face-to-face, is now turning online. This is the impact of the government's policy to limit large-scale social activities to prevent the development of the coronavirus. In 2020, the number of chat exchanges on the Tinder app increased by 23\%. Nowadays people prefer to get to know others online before deciding to meet in person. Social Penetration Theory (TPS) can be used to analyse the process of communication and self-disclosure of an individual in building interpersonal relationships. This theory describes a person like an onion that has various layers in it because someone only provides general information in the early stages of a relationship then reveals more personal information when they get close and build trust. This research is different from previous work because it analyses TPS on Tinder application users during the Covid-19 pandemic. This study aims to review TPS on Tinder application users by testing the main assumptions of the theory in relationship development and self-disclosure. This study uses a qualitative approach. Data collection is done by searching for articles journals with keywords TPS and the use of Tinder application to build relationships. The results show that the self-disclosure mediated by digital technology can limit the general and personal information shared by its users. The limitation of it lies in the ability to read non-verbal messages. Gender factors influence how individuals build relationships in the early stages. Men tend to approach women aggressively using jokes or funny statements, while women rely more on subtle cues. Future research can focus on the communication of Tinder application users at different age ranges. This research is expected to be input for research on online communication, self-disclosure and relationship development.
\end{abstract}

Keywords: Social Penetration Theory (SPT); Online Dating Apps; Self-Disclosure; Relational Development; Interpersonal Relationship. 


\begin{abstract}
Abstrak
Pandemi Covid-19 telah merubah perilaku sosial di masyarakat. Khususnya pada proses membangun hubungan antar lawan jenis yang biasanya dilakukan secara tatap muka sekarang beralih secara daring. Hal ini merupakan dampak dari kebijakan pemerintah untuk membatasi kegiatan sosial berskala besar guna mencegah perkembangan virus corona. Pada tahun 2020, jumlah pertukaran percakapan di aplikasi Tinder meningkat sebesar 23\% bersamaan dengan masuknya virus corona ke Indonesia. Saat ini orang lebih memilih untuk mengenal lawan jenis lewat daring sebelum memutuskan untuk bertemu langsung. Teori Penetrasi Sosial (TPS) dapat digunakan untuk menganalisis proses komunikasi dan pengungkapan diri seorang individu dalam membangun hubungan interpersonal. Teori ini mengibaratkan seseorang sebagai sebuah bawang yang memiliki berbagai lapisan di dalamnya karena seseorang cenderung hanya memberikan informasi umum pada tahap awal hubungan kemudian mengungkapkan informasi yang lebih personal ketika sudah memiliki kedekatan dan kepercayaan dengan orang tersebut. Penelitian ini berbeda dengan riset yang dilakukan sebelumnya karena menganalisis TPS pada pengguna aplikasi Tinder di masa pandemi Covid-19. Penelitian ini bertujuan untuk mengulas TPS pada pengguna aplikasi Tinder dengan menguji asumsi utama teori dalam pengembangan hubungan dan pengungkapan diri. Penelitian ini menggunakan pendekatan kualitatif. Pengumpulan data dilakukan dengan mencari artikel yang menggunakan kata kunci TPS dan penggunaan aplikasi Tinder untuk membangun hubungan. Hasil penelitian menunjukkan bahwa proses pengungkapan diri yang dimediasi teknologi digital dapat membatasi informasi umum dan personal yang dibagikan penggunanya. Keterbatasan komunikasi yang termediasi terletak pada kemampuan untuk membaca pesan non verbal. Penemuan menarik lainnya yaitu faktor jenis kelamin yang mempengaruhi bagaimana individu membangun hubungan pada tahap awal. Pria cenderung mendekati wanita dengan agresif seperti menggunakan gombalan atau kalimat lucu sedangkan wanita lebih mengandalkan isyarat halus. Penelitian selanjutnya dapat memfokuskan proses komunikasi dari pengguna aplikasi Tinder pada rentang umur yang berbeda untuk membandingkan hasilnya. Penelitian ini diharapkan dapat menjadi masukan pada riset mengenai komunikasi daring, pengungkapan diri dan pengembangan hubungan.
\end{abstract}

Kata Kunci: Teori Penetrasi Sosial, Aplikasi Kencan Online, Pengungkapan Diri, Pengembangan Hubungan, Komunikasi Interpersonal.

\title{
PENDAHULUAN
}

Kebijakan pemerintah untuk memberlakuan Pembatasan Sosial Berskala Besar (PSBB) secara perlahan telah merubah perilaku dan kebiasaan kita sehari-hari. Salah satunya dalam hal bersosialisasi. Kementerian Komunikasi dan Informasi (KOMINFO) mengumumkan bahwa penggunaan internet di tengah pandemi COVID-19 telah meningkat sebesar $40 \%$ bahkan diperkirakan akan terus bertambah untuk kedepannya (Tempo, 2020). Sebagian besar orang mengakses internet untuk memperoleh informasi, membuka social media, mengunjungi situs belanja online serta aplikasi kencan online.

Tingginya pengguna internet di masa pandemi menunjukan bahwa sebagian besar orang menghabiskan waktu mereka di depan layar smartphone ataupun gadget lain saat tidak bisa bepergian keluar rumah. Kehadiran social media dan aplikasi seperti Tinder memudahkan proses komunikasi dengan dengan pengguna lainnya yang berjarak ribuan kilometer jauhnya. Proses pengungkapan diri dalam membangun hubungan interpersonal secara online menjadi hal yang menarik untuk diteliti.

Salah satu aplikasi kencan online yang cukup terkenal adalah Tinder. Aplikasi ini diluncurkan oleh Sean Read, Justin Mateem dan Jonathan Badin yang berasal dari West Hollywood, California pada tahun 2012. Tinder dilengkapi dengan satelit navigasi sehingga dapat mempertemukan sesama pengguna aplikasi dilingkungan sekitarnya. Pada tahun 2020, 
data pengguna Tinder di Indonesia menunjukkan peningkatan sebesar 23 persen untuk ratarata percakapan harian dan peningkatan 19 persen untuk durasi rata-rata percakapan dibandingkan sebelumnya. Berdasarkan data ini, dapat dipahami bahwa social and physical distancing membantu kita menyadari bahwa hubungan yang dibentuk melalui sarana digital memiliki makna yang sama dengan yang dibuat secara langsung atau saat tatap muka (Jakarta Post, 2020).

Meningkatnya jumlah pertukaran percakapan di aplikasi Tinder menggambarkan bahwa pengguna menjadi lebih aktif untuk bertukar informasi dengan pengguna lainnya di masa pandemi. Terdapat beberapa faktor yang mempengaruhinya seperti kesepian, kurangnya penguatan positif, hiburan, keinginan mencari komitmen dan keintiman sosial ditengah ketidakpastian mengenai berakhirnya pandemi (Joshi, 2021: 29). Munculnya aplikasi kencan online seperti Tinder telah merubah cara mencari pasangan kencan yang sebelumnya dilakukan melalui pertemuan tatap muka sekarang beralih menjadi pertemuan online. Sebelum bertemu langsung, para pengguna Tinder berinteraksi secara online dimana pengguna mulai bertukar informasi diri sebagai proses untuk membangun hubungan. Proses tersebut dapat diteliti menggunakan teori penetrasi sosial (SPT) dari Altman dan Taylor yang memberi perhatian pada jenis informasi yang diungkapkan (depth of penetration) dan keragaman informasi yang dimiliki suatu individu untuk diungkapkan (breadth of penetration). Penelitian ini bertujuan untuk mengetahui bagaimana implementasi teori penetrasi sosial serta konsep pengungkapan diri pada pengguna aplikasi Tinder di masa pandemi Covid-19.

\section{TINJAUAN LITERATUR}

\section{Teori Penetrasi Sosial}

Irwin Altman dan Dalmas Taylor merupakan kedua tokoh yang mempopulerkan Teori Penetrasi Sosial pada tahun 1973. Mereka berpendapat bahwa setiap orang memiliki sistem pengaturan mengenai informasi yang diketahui dirinya sendiri dan orang lain (Littlejohn, 2016: 224). Analogi yang sering digunakan adalah dengan membayangkan seseorang seperti bawang dengan lapisan yang bisa dikupas, ketika suatu hubungan berkembang, mitra relasional bergerak melampaui lapisan awal, terus mengupas untuk mencapai pengungkapan yang lebih dalam atau penting bagi setiap orang dalam hubungan sebagai individu (Pennington, 2015: 5).

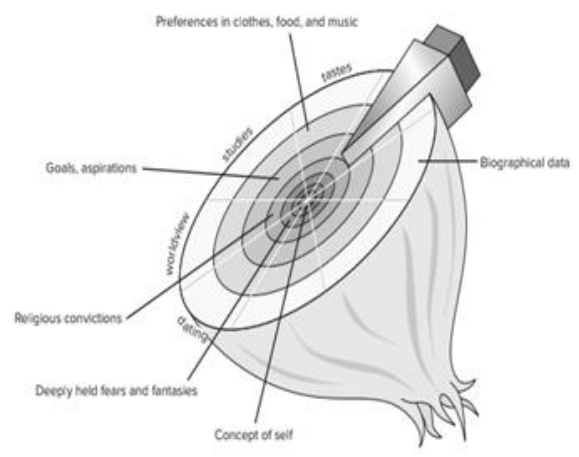

Gambar 1. Teori Penetrasi Sosial 
Teori Penetrasi Sosial oleh Taylor (1968: 79) bertujuan untuk memberikan kerangka kerja yang dapat menggambarkan perkembangan hubungan interpersonal yang berjalan di sepanjang dua dimensi terkait yaitu, keluasan penetrasi (breadth of penetration), atau jumlah interaksi, pertukaran informasi, dll., per satuan waktu (misalnya, jumlah komunikasi per minggu), dan kedalaman penetrasi (depth of penetration) atau derajat keintiman dari interaksi oleh antar individu. Menurut Kurniawan, Hadi dan Irwansyah (2021: 45) informasi yang dibagikan oleh individu dalam teori ini berkaitan dengan pikiran, perasaan dan sikap seseorang.

\section{Depth of Penetration (Kedalaman Penetrasi)}

Altman dan Taylor (1973) mengungkapkan empat lapisan dalam pengungkapan diri menurut SPT yaitu: (1) Pengungkapan permukaan (surface disclosure) mengacu pada pengungkapan informasi dengan memasukan fakta yang sangat dangkal; hal-hal yang dapat dipelajari hanya dengan melihat seseorang atau tidak menyinggung untuk didiskusikan (misalnya, pembicaraan mengenai cuaca). (2) Pengungkapan periferal (peripheral disclosure) adalah informasi yang akan dibagikan oleh sebagian orang yang tidak membutuhkan keintiman apa pun, ini adalah tempat dimana seseorang bisa berbicara dengan orang lain yang mengenakan kemeja tim basket Chicago Bulls dengan berkata, "Oh hai, saya juga suka Bulls!" meskipun dirinya sendiri tidak memakai apa pun yang menunjukkan informasi itu. (3) Pengungkapan menengah (intermediate disclosure) adalah informasi yang akan lebih selektif untuk diungkapkan seseorang; terkait dengan bagaimana perasaan seseorang tentang sesuatu, suka atau tidak suka yang melampaui tingkat dasar dari ketertarikan pada film, olahraga, dll. Contohnya pada keberpihakan politik, misalnya "Saya memilih Republikan karena menurut saya kita memerlukan kebijakan imigrasi yang lebih ketat". (4) Lapisan terakhir bersifat sentral (central disclosure) dan mencakup informasi pribadi yang dipandang sebagai intimasi atau keakraban dan hanya dibagikan dengan mereka yang merupakan teman yang sangat dekat, mitra relasional dan/atau keluarga. Ingatlah contoh sebelumnya mengenai penggemar Bulls, sebagai pengungkapan periferal tentang tim yang disukai, mungkin ada cerita yang terkait dengan pengalaman masa lalu dan keluarga dibaliknya.

\section{Breadth of Penetration (Keluasan Penetrasi)}

Luasnya komunikasi juga penting dalam pengembangan relasional. Kategori luas mengacu pada area umum informasi atau topik yang mungkin dibahas, satu lapisan mungkin mulai mengelupas tetapi ada juga segmen yang berbeda juga. Misalnya, seseorang mungkin mulai mengungkapkan informasi tentang musik dan sekolah dengan seseorang, tetapi bukan tentang keluarga atau politik. Frekuensi luas mengacu pada seberapa banyak yang dapat diungkapkan dalam setiap kategori, beberapa informasi lebih dangkal dan beberapa lebih pribadi, dengan beberapa kategori memiliki kedalaman lebih dari yang lain. SPT mengungkapkan bahwa setelah kategori yang sudah dibuat dapat diakses maka akan terus berlanjut dengan peningkatan jumlah waktu (untuk membahas kategori) sebagai proses penetrasi sosial yang berlangsung (Pennington, 2015: 5-6).Tinjauan literature langsung mengarah ke teori yang digunakan 



\section{METODE PENELITIAN}

Penelitian ini menggunakan pendekatan kualitatif dengan tujuan akhir untuk menghasilkan data deskriptif berupa teks (Bogdan \& Taylor, 1975: 5). Metode penelitian pada literature review ini menggunakan analisis isi yang dimulai dari pencarian artikel pada sebuah basis data jurnal penelitian, pencarian secara daring dan tinjauan ulang artikel. Pencarian database dilakukan dengan menelusuri Sage Publications, Emerald Insight, Elsevier dan Google Scholars. Kata kunci yang digunakan dalam pencarian artikel yaitu Social Penetration Theory, Online Dating dan Self-Disclosure. Penelitian ini menggunakan kriteria dari Collins dan Miller, 1994 bahwa sebuah penelitian harus mengandung manipulasi atau ukuran laporan pengungkapan diri (studi bisa korelasional atau eksperimental). Hanya penelitian yang divariasikan baik dalam jumlah (luasnya) pengungkapan (seperti waktu yang dihabiskan untuk berkomunikasi), atau tingkat keintiman (kedalaman) pengungkapan (seperti topik dangkal vs. pribadi) yang dimasukkan. Terdapat 4 artikel yang sesuai kriteria penelitian ini yang dianalisis melalui analisis tujuan, kesesuaian topik topik penelitian, metode penelitian, hasil setiap artikel penelitian, serta batasan batasan yang ada.

\section{HASIL DAN PEMBAHASAN}

\section{Konsep Penetrasi Sosial dalam Online Dating Apps}

Implementasi penetrasi sosial sebagai strategi dalam online dating mengenai pengungkapan dan pencarian informasi secara interpersonal bisa dikaji menggunakan konsep incremental disclosure atau pengungkapan bertingkat dalam lingkup Social Penetration Theory, yang klasifikasinya dibuat oleh Altman dan Taylor pada tahun 1973. Sharabi dan DeVette (2019) dalam penelitiannya menyatakan bahwa kencan online telah berkembang pada penentuan pasangan dan memiliki beberapa perubahan secara luas dari pacaran tradisional yang terlihat dalam beberapa dekade terakhir. Menurut Merkle \& Richardson (2000) hubungan kencan online tidak selalu mengikuti model tradisional, yang lebih mengutamakan bertemu secara langsung, namun dengan cara menyimpan data online ke profil virtual dan sebagian komunikasi awal mereka terjadi secara eksklusif melalui media sosial yang biasanya mengandalkan tatap muka.

Strategi permulaan hubungan berdasarkan pendapat dari Wotipka \& High (2016) menyatakan kemungkinan besar orang menggunakan kombinasi strategi yang berbeda ketika berinteraksi dalam kencan online untuk memahami proses komunikasi seputar permulaan dalam hubungan secara lebih luas. Schoendienst dan Dang-Xuan (2011) menganalisis 167.276 pesan kencan online. Temuan mereka mengamati perbedaan terkait gender bahwa pria cenderung langsung dalam mendekati wanita, sedangkan wanita mengandalkan isyarat lebih halus untuk menunjukkan ketertarikan daripada pria.

Sejalan dengan penelitian yang dilakukan oleh Finkel dan Eastwood mengenai kebiasaan pria yang secara langsung mendekati daripada didekati oleh wanita dalam acara kencan yang pertama kali baik secara online maupun offline, Finkel et al., (2012) menyampaikan bahwa kebanyakan dari kencan online yaitu untuk menemukan seseorang untuk berkencan secara langsung dengan cara menyarankan saat komunikasi online sebelum kencan pertama harus memberikan dasar yang kuat untuk tetap bersama ketika di kehidupan yang nyata. Akan tetapi menurut (Ramirez \& Zhang, 2007) menyatakan bahwa kencan pertama tidak selalu baik, terbukti bahwa CMC hyperpersonal dapat mengarah pada 
kekecewaan jika pasangan gagal memenuhi harapan yang lebih baik satu sama lain yang terkadang tinggi setelah bertemu.

Strategi berikutnya yang dibahas dalam penelitian Sharabi dan DeVette (2019) ini adalah strategi untuk membangun keaslian karakter diri. Kategori ini ditentukan dengan penggunaan dua strategi untuk membangun kredibilitas dalam presentasi diri online: (a) menjamin dan (b) mencela diri sendiri. Strategi penjaminan $(11,4 \%)$ menunjukkan kebutuhan untuk mengkonfirmasi identitas online menggunakan informasi luar. Meskipun teori CMC secara dominan menyatakan bahwa presentasi diri yang positif, peserta sering melakukan penghinaan diri atau self deprecation (29,5\%). Penghinaan diri digunakan untuk mengekspresikan pandangan negatif tentang diri melalui keluhan dan kritik yang diarahkan oleh peserta.

Strategi untuk menciptakan konteks bersama untuk interaksi yang mencakup tiga strategi untuk menciptakan "konteks sosial bersama" seputar pribadi peserta dan pengalaman kencan online: (a) sikap kencan online, (b) dianggap homofili, dan (c) mencatat ketidaksamaan. Sejumlah peserta mengungkapkan sikap kencan online mereka $(12,4 \%)$ melalui pernyataan yang mengkritik atau memuji kemampuan, fitur, atau kegunaan situs. Sikap negatif terhadap kencan online termasuk komentar dari peserta yang mengatakan mereka merasa lebih sulit untuk menulis daripada berbicara secara real time. Dianggap hemofilia. Sebagai sebuah strategi, persepsi dan homofili $(48,6 \%)$ mereferensikan kesamaan peserta dengan pasangan mereka, termasuk pernyataan yang menunjukkan persetujuan atau menyoroti minat, sikap, atau nilai bersama. Strategi mendaftarkan ketidaksamaan $(14,3 \%)$ adalah cara bagi peserta untuk mendiskusikan area perselisihan dan perselisihan dengan pasangan mereka. Strategi untuk mengungkapkan dan mencari informasi pribadi. Peserta menggunakan tiga strategi untuk mengungkapkan dan meminta informasi: (a) pengungkapan tambahan (peripheral, menengah, dan inti) berdasarkan klasifikasi Altman and Taylor (1973), (b) mengatasi ketidakpastian, dan (c) referensi profil.

\section{Implementasi Teori Penetrasi Sosial pada Pengguna Aplikasi Kencan Online}

Proses pengungkapan diri membutuhkan timbal balik, artinya seseorang cenderung membuka diri terhadap orang yang juga mau terbuka (West \& Turner, 2007: 191-192). Tahapan hubungan itu dialektis dan non-linier. Seperti yang kita semua tahu, komunikasi tatap muka memiliki hak istimewa untuk tidak menunda umpan balik. Fungsi umpan balik dalam komunikasi tatap muka adalah agar komunikator dapat memahami apakah pesan yang disampaikan dapat diterima dengan baik oleh komunikator, begitu pula sebaliknya. Sementara itu, peran teknologi tentunya sangat diperlukan jika berbicara tentang perantara komunikasi (Kurniati, 2015: 30). Teknologi tidak hanya menciptakan jenis komunikasi interpersonal baru, tetapi juga mengubah cara orang berinteraksi (Kurniati, 2015: 30).

Temuan dari penelitian Ruppel (2015) memberikan wawasan tentang penggunaan Teknologi Informasi dan Komunikasi (TIK) dan hubungan romantis. Selain menjawab pertanyaan tentang hubungan antara penggunaan TIK dan pengungkapan diri dalam percakapan tertentu dalam hubungan ini, temuan memperluas penelitian sebelumnya yang memeriksa TIK berbasis suara dan dengan mengeksplorasi perannya dalam pengembangan hubungan dalam pengungkapan diri melalui TIK. 
Implementasi Teori Penetrasi Sosial sudah dikembangkan dalam berbagai penelitian terdahulu dengan memasukkan berbagai konsep mengenai hubungan interpersonal lainnya. Dalam hubungan dekat, pengungkapan diri dapat mengekspresikan dan meningkatkan keintiman (Derlega et. al, 1993). Teori penetrasi sosial (Altman \& Taylor, 1973) mengidentifikasi dimensi luas dan kedalaman pengungkapan diri yang sangat relevan dengan pengembangan dan pemeliharaan hubungan. Derajat pengungkapan berkaitan dengan konten atau aspek kepribadian yang diungkapkan orang, sedangkan kedalaman pengungkapan berkaitan dengan keintiman informasi di area konten tertentu (Altman \& Taylor, 1973; Taylor \& Altman, 1987). Luasnya pengungkapan diri telah dikaitkan dengan kepastian (Tidwell \& Walther, 2002), keintiman (Tolstedt \& Stokes, 1984), perasaan aman dalam hubungan (Prisbell \& Andersen, 1980), kedalaman keterbukaan diri telah dikaitkan dengan kedekatan, kualitas relasional dan kepastian. Seseorang yang berkomunikasi melalui TIK berbasis teks seperti pesan instan cenderung mengungkapkan dengan frekuensi yang lebih besar (Ruppel, 2015) dan intim (Jiang et al., 2013; Tidwell \& Walther, 2002) daripada yang berkomunikasi dengan tatap muka. TIK menawarkan lebih sedikit isyarat (misalnya, informasi verbal, vokal, atau visual) dibandingkan dengan komunikasi tatap muka. Seperti yang diamati Baym (2002: 8) bahwa "gagasan tentang isyarat sosial yang berkurang tetap sentral" ke studi tentang teknologi komunikasi. Satu tes dari ide ini menemukan bahwa pengungkapan diri terjadi lebih sering dalam interaksi berbasis teks daripada dalam interaksi berbasis video (Joinson, 2001), seperti pada mobile dating apps yang umum dipakai di Indonesia seperti Tinder

Pada jurnal dengan judul "Swiping, Matching, Chatting: Presentasi Diri dan Pengungkapan diri pada Mobile Dating Apps" oleh Ward (2016) dilandasi pemikiran bahwa kegiatan kencan pertama (first dating) diyakini sebagai langkah awal dalam membina suatu hubungan yang romantis antara sepasang kekasih. Kencan pertama dari masa ke masa semakin berkembang, dimulai dari kencan dalam bentuk pertemuan langsung antara dua orang, kemudian disusul oleh kencan melalui media massa, hingga pada akhirnya muncul pula kencan digital melalui aplikasi perjodohan online.

Disadari maupun tanpa disadari, baik itu kencan secara langsung, melalui media massa ataupun melalui aplikasi perjodohan online, semuanya bermula dari pendekatan teori yang sama, yakni teori penetrasi sosial. Dimulai dengan promosi diri yang dikemas sedemikian rupa agar bisa menarik pasangannya, diteruskan dengan membentuk sebuah hubungan yang saling mengungkapkan jati diri masing-masing hingga akhirnya membina sebuah hubungan yang romantis. Oleh karenanya jurnal ini hadir untuk menjawab berbagai persoalan terkait hubungan antara penerapan teori penetrasi sosial (social penetration theory) terhadap proses kencan pertama secara digital yang dilakukan dalam aplikasi perjodohan online. Salah satu aplikasi yang akan diteliti dalam jurnal ini adalah aplikasi kencan digital bernama Tinder.

Pembentukan suatu hubungan yang romantis biasanya diawali dengan kesan yang muncul setelah kencan pertama. Dalam berbagai budaya di dunia ini, kencan pertama diidentifikasi sebagai langkah awal untuk saling menarik atensi dari lawan jenis. Lazimnya, mereka sering menghabiskan waktu bersama dengan saling berbagi informasi pribadi, sehingga kemudian mereka saling terhubung satu sama lain. Seiring dengan perkembangan 
zaman, kencan pertama tak melulu mesti dilakukan dengan pertemuan secara langsung, melainkan dapat juga dilakukan secara virtual.

Kencan secara digital dilakukan dengan cara seseorang mesti memilih terlebih dahulu aplikasi apa yang akan digunakannya. Salah satu apps yang umum dimanfaatkan untuk media kencan digital adalah aplikasi Tinder. Aplikasi Tinder dapat diakses dari smartphone setiap orang dan dapat memberikan preferensi pasangan ideal sesuai kedekatan geografis, potensi kecocokan hingga rentang usia, sehingga berkat kemudahan dan kecanggihan aksesnya ini banyak orang yang tertarik untuk mencari pasangan yang sesuai dengan kriterianya. Melalui aplikasi ini, seseorang bisa mulai memilih pria atau wanita yang diminatinya hanya berbekalkan foto profil dan deskripsi singkat yang secara otomatis tersambung dengan Facebook.

Proses pencarian pasangan yang diminatinya pun terbilang mudah. Pengguna hanya cukup menggerakkan kursor ke kanan jika dia merasa cocok dengan preferensi yang diberikan oleh aplikasi Tinder, dan cukup menggerakan kursor ke kiri. apabila dia tidak merasa cocok dengan preferensi yang diberikan oleh aplikasi Tinder tersebut. Selanjutnya, ketika pengguna tersebut menggerakkan kursor ke kanan dan si lawan jenisnya menggeserkan kursornya kepada profil si pengguna, maka otomatis pengguna dan lawan jenisnya akan bisa saling terhubung untuk melakukan chatting dalam aplikasi. Namun, meskipun memiliki kemudahan dalam aksesnya, penggunaan Tinder dalam kegiatan kencan pertama ini, nyatanya belum banyak diteliti dalam kajian sudut pandang psikologi terutama terkait presentasi dan pengungkapan diri dalam kegiatan menjalin sebuah hubungan.

Padahal menurut Goffman (1959) dalam Ward (2016: 84), presentasi diri atau yang bisa disebut juga pencitraan diri merupakan hal yang penting dan ada dalam kehidupan sosial orang-orang, yang mana setiap individu ketika mempresentasikan dirinya sendiri mereka senantiasa mencoba untuk mengendalikan atau mengarahkan atensi serta kesan orang lain melalui manipulasi pengaturan, penampilan, serta perilaku. Pendapat Goffman tersebut kemudian dipertegas oleh Leary dan Kowalski (1990) dalam Ward (2016: 85) yang mendefinisikan dua kunci sukses dalam proses presentasi atau pencitraan diri terdiri atas (1) pemberian impresi yang memotivasi orang lain agar mau berkenalan atau bahkan ingin menggunakan aplikasi yang sama dengan pengguna; (2) menyunting atau meng-edit tayangan profil untuk mengontrol kesan yang membuat orang penasaran. Walther, dalam Ward (2016: 85) menambahkan, presentasi atau pencitraan diri dalam konteks komunikasi melalui aplikasi kencan digital sesungguhnya memiliki konsep yang serupa dengan komunikasi tatap langsung secara konvensional.

Namun, letak perbedaan yang paling mencolok dalam komunikasi kencan digital ini terdapat pada penggabungan konsep kontekstual, visual, dan audio visual dalam komunikasinya. Sehingga tak jarang terjadi penipuan terkait pengadaan foto profil, tinggi dan berat badan, hingga usia dikarenakan informasi mengenai presentasi atau pencitraan diri dilakukan secara selektif, terbatas dan berada di bawah kendali langsung pengguna. Didukung oleh data penelitian Ward (2016) melalui wawancaranya.

Berdasarkan hasil wawancara tersebut, diketahui bahwa dalam aplikasi Tinder pengguna biasanya mulai menyeleksi pasangan mana yang hendak ia pilih melalui penampilan foto profilnya. Jika foto profil yang ditampilkan sesuai dengan kriteria yang diusung, maka pengguna akan meneruskan perkenalan diantara mereka melalui layanan 
chatting dalam aplikasi tersebut, meskipun pengguna tidak mengetahui apakah foto profil dan deskripsi informasi yang digunakan itu asli atau palsu. Hal ini tampaknya memang wajar terjadi karena, pencitraan memang dibutuhkan untuk bisa menarik atensi dan minat orang lain agar mereka mau setidaknya memeriksa foto dan informasi kita. Pada akhirnya meskipun dipenuhi ketidakpastian akan informasi pribadi, nyatanya aplikasi Tinder ini masih menjadi primadona bagi orang - orang.

Hal ini sesuai dengan pendapat Goffman dalam Ward (2016: 87) yang menyatakan bahwa meskipun kencan digital dilakukan dengan cara tidak bersentuhan fisik, para pengguna Tinder tetap mampu merasakan sensasi dan membayangkan bahwa calon pasangan yang mereka pilih sudah tepat dan cocok sesuai kriteria mereka. Asumsi mereka memanglah tidak terlalu salah, karena ternyata setelah proses pemilihan calon pasangan terjadi, para pasangan ini difasilitasi oleh Tinder untuk saling mengungkapkan dirinya dalam sebuah obrolan serius melalui tatap muka virtual. Rupanya asumsi mereka tersebut diakomodasi oleh Collins dan Miller (1994) dalam Janelle Ward (2016: 88) yang menyatakan bahwa pengungkapan diri merupakan aspek penting dalam mengembangkan sebuah hubungan. Pengungkapan diri ini dapat didefinisikan sebagai tindakan untuk mengungkapkan berbagai informasi tentang pribadi kepada orang lain.

Pengungkapan diri bisa meliputi beberapa informasi deskriptif terkait hobi seseorang, pengalaman masa lalu seseorang, hingga hal-hal detail lainnya. Pengungkapan kepribadian ini oleh Altman dan Taylor (1973) dalam Ristiana Kadarsih (2009: 55) disebut sebagai model kepribadian bawang dimana informasi informasi biografi terdapat pada kulit terluar dan semakin dalam terdapat informasi tentang diri yang lebih private. Presentasi atau pencitraan diri serta pengungkapan diri sejatinya termasuk ke dalam ranah teori penetrasi sosial yang dicetuskan oleh Altman dan Taylor (1975). Kadarsih (2009: 5) mengungkapkan, konsep ini mampu menjelaskan bagaimana sebuah hubungan kedekatan bisa mengalami perkembangan yang terbentuk melalui sebuah hubungan interpersonal yang kemudian berubah menjadi hubungan teman baik melalui berbagai proses tahapan dan bentuk yang teratur dari tingkat permukaan hingga bagian intim sebuah hubungan.

Imbasnya, ketika terjadi sebuah perkembangan hubungan, keluasan dan kedalaman hubungan tersebut akan semakin meningkat. Terkait dengan hal tersebut, presentasi atau pencitraan diri merupakan bentuk branding diri kita dalam proses komunikasi interpersonal dalam mencari pasangan ideal sesuai kriteria yang telah kita tentukan, sementara itu pengungkapan diri merupakan inti dari proses komunikasi interpersonal yang merupakan jalan bagi orang lain untuk dapat mengetahui apa yang terjadi pada diri kita, apa yang kita rasakan serta apa yang dipikirkan dan apa yang kita pedulikan. Efek dari pengungkapan diri ini dapat mengurangi kecemasan yang menerpa kita, menumbuhkan kenyamanan, dan memperkuat ketertarikan interpersonal. Sehingga imbasnya, semakin intim sebuah hubungan yang kita jalani, semakin kuat pula komitmen dan kontrak emosi yang ditunjukan oleh rasa saling percaya dalam hubungan.

Pada kasus di Indonesia dalam penelitian yang dilakukan oleh Fridha \& Octavianti (2016), laki-laki di Jakarta cenderung menganggap online dating applications layaknya belanja online karena mereka tinggal memilih dan menyeleksi yang sesuai dengan kriteria mereka dan menggunakan kata-kata pembuka yang menarik perhatian (kata-kata gombal) untuk menginisiasi hubungan online dating tahap pertama/awal. Namun bagi perempuan, 
mereka biasanya akan mencari informasi mengenai pasangannya secara diam-diam daripada bertanya langsung supaya tidak terlihat terlalu agresif (Sespiani, Aprilia, Irwansyah : 2021)

Sedangkan pada kasus lain seperti di India, pengguna aplikasi online dating seperti Tinder mengungkapkan bahwa tujuan utamanya adalah untuk menghilangkan stress dan mengurangi rasa kesepian (Joshi, 2021). Pengguna aplikasi di luar negeri cenderung menyapa lawan jenis seperti biasa dan lebih aktif untuk mengajak bertemu langsung, namun ketika mereka tidak merasa nyaman dengan topik yang diperbincangkan maka mereka akan menghilang "ghosting" dan mengabaikan pesan dari lawannya tersebut. Pengguna yang memiliki ketertarikan seksual dan termasuk dalam LGBTQIA lebih sering menerima perlakuan bullying daripada pengguna lain (Marston et al., 2020: 13-14).

Tabel 1

Review Artikel Jurnal

Detail Judul Hasil Penelitian

\begin{tabular}{|c|c|c|}
\hline Penulis: & Swiping, & 1. Motivasi pengguna Tinder baik sekedar \\
\hline Ward, Janelle & $\begin{array}{l}\text { Matching, } \\
\text { Chatting: Self- }\end{array}$ & $\begin{array}{l}\text { hiburan atau mencari pasangan dapat } \\
\text { berubah seiring waktu }\end{array}$ \\
\hline$\frac{\text { Tahun terbit: }}{2016}$ & $\begin{array}{l}\text { Presentation and } \\
\text { Self-Disclosure } \\
\text { on Mobile Dating }\end{array}$ & $\begin{array}{l}\text { 2. Pengguna aplikasi bisa menggunakan } \\
\text { teknologi untuk mengurangi ketidakpastian } \\
\text { pada calon pasangan }\end{array}$ \\
\hline$\frac{\text { Metode Penelitian: }}{\text { Deskriptif Kualitatif }}$ & Apps & $\begin{array}{l}\text { 3. Presentasi diri memiliki peran vital pada } \\
\text { pembentukan impresi begitu juga } \\
\text { pengungkapan diri untuk membangun } \\
\text { hubungan }\end{array}$ \\
\hline $\begin{array}{l}\text { Penulis: } \\
\text { Ruppel, Erin. } \mathrm{K}\end{array}$ & $\begin{array}{l}\text { Use of } \\
\text { communication } \\
\text { technologies in }\end{array}$ & $\begin{array}{l}\text { 1. Pasangan dalam hubungan yang lebih } \\
\text { berkembang melaporkan penggunaan } \\
\text { komunikasi teknologi berbentuk teks yang }\end{array}$ \\
\hline Tahun terbit: & romantic & lebih rendah dari proporsi total komunikasi \\
\hline 2015 & $\begin{array}{l}\text { relationships: } \\
\text { Self-disclosure }\end{array}$ & $\begin{array}{l}\text { 2. Terdapat interaksi yang signifikan antara } \\
\text { pengembangan hubungan dengan }\end{array}$ \\
\hline Metode Penelitian: & and the & penggunaan komunikasi teknologi \\
\hline Deskriptif & role of & berbentuk suara \\
\hline Kuantitatif, Analisis & relationship & 3. Terjadi pembatasan pengungkapan \\
\hline Regresi & development & $\begin{array}{l}\text { informasi umum maupun personal pada } \\
\text { komunikasi melalui teknologi sebagai } \\
\text { perantara dibandingkan dengan komunikasi } \\
\text { tatap muka }\end{array}$ \\
\hline
\end{tabular}




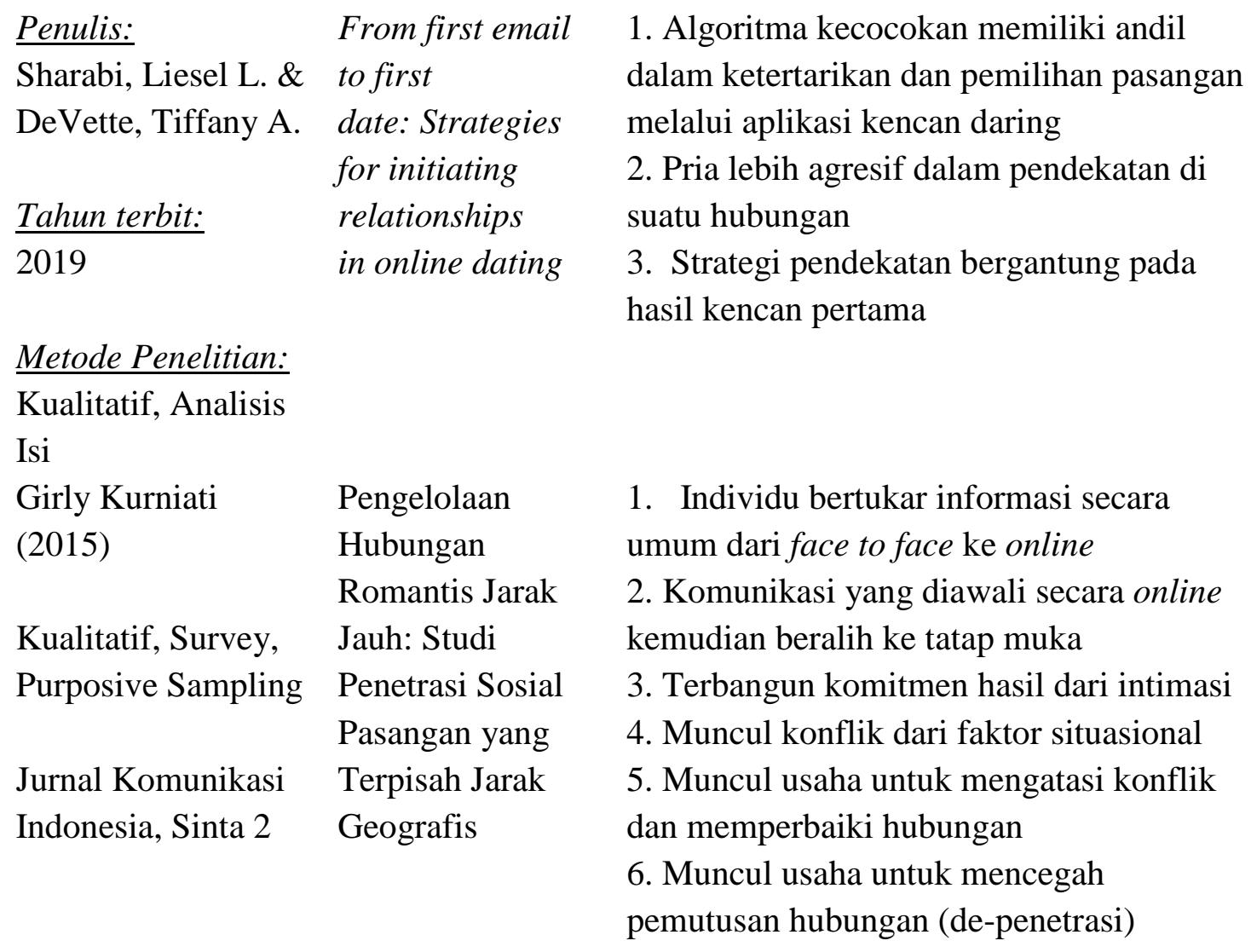

Sumber: Diolah oleh penulis, 2020

\section{Development of The Theory}

Awalnya, teori penetrasi sosial penting dalam memusatkan perhatian kita pada pengembangan hubungan sebagai proses komunikasi, akan tetapi hal itu tidak sesuai dengan pengalaman hubungan aktual dalam kehidupan sehari-hari. Misalnya, pasangan tidak membuat keputusan untuk mengungkapkan/tidak mengungkapkan hanya berdasarkan biaya dan penghargaan individu. Sebaliknya, mereka harus bersama-sama mencari tahu apakah akan mengungkapkan atau menyembunyikan jika ada alasan bagus untuk melakukan keduanya. Oleh karena itu, teori komunikasi manajemen privasi (CPM) hadir untuk menyempurnakan teori penetrasi sosial. Teori CPM lebih baru dan kompleks. Teori ini membahas ketegangan antara keterbukaan dan privasi pada ranah "publik" dan "pribadi".

Selain itu, teori penetrasi sosial terbatas pada pengembangan hubungan interpersonal sehingga Altman dan Taylor meminjam konsep teori pertukaran sosial dari seorang psikolog John Thibaut dari Universitas North California di Chapel Hill dan Harold Kelley dari Universitas California di Los Angeles dalam menjelaskan kapan dan mengapa individu tersebut melanjutkan dan mengembangan hubungan, begitu juga dengan mengakhiri suatu hubungan (Dainton, 2018: 133). Teori ini memiliki tiga komponen utama yang memperhatikan kondisi mental individu, yaitu: Relational Outcome (hasil dari suatu hubungan), Relational Satisfaction (kepuasan dari suatu hubungan) dan Relational Stability (stabilitas hubungan). 


\section{Critique to the Theory}

Penggunaan teori penetrasi sosial sangat baik jika digunakan untuk mengkaji hubungan tatap muka (face to face) namun teori ini gagal membahas lebih dalam mengenai pertukaran pesan yang dimediasi dengan isyarat tidak langsung (non verbal) pada fenomena online dating. Peneliti menyarankan untuk mengembangkan penelitian ini dengan mempertimbangkan teori computer mediated communication (CMC) yang membahas mengenai proses komunikasi antar manusia yang dimediasi oleh komputer serta keterlibatan pada proses penggunaan saluran media untuk mencapai berbagai tujuan (Thurlow et al, 2017: 16).

\section{KESIMPULAN}

Berdasarkan hasil dari ulasan literatur yang dilakukan pada beberapa jurnal yang sudah terkumpul, dapat ditarik kesimpulan bahwa pengungkapan diri seorang individu melalui aplikasi online dating khususnya Tinder dipengaruhi oleh presentasi diri yang mampu menarik perhatian pengguna aplikasi online dating lain. Proses pertukaran pengungkapan diri yang menjadi salah satu poin utama teori penetrasi sosial dari Altman dan Taylor (1975) memiliki tingkatan atau increment yang bisa dimulai dari pengungkapan biodata yang terpampang pada profil online dating app, dan kemungkinan apakah hubungan tersebut bisa terus berlanjut bila terdapat kesamaan kesukaan atau kesesuaian ekspektasi seseorang terhadap pasangannya. Perkembangan dalam implementasi teori Penetrasi Sosial ini bisa digunakan dalam lingkup CMC atau Computer Mediated Communication dengan menganalisis kasus menggunakan kerangka teoritik dari konsep atau teori lain seperti presentasi diri, pengurangan ketidakpastian, pertukaran sosial dan manajemen privasi.

Jurnal ini memperkuat penggunaan konsep teori penetrasi sosial. Ward (2016) membuktikan bahwa segala aktivitas yang dilakukan dan difasilitasi oleh aplikasi Tinder ini termasuk di dalamnya kegiatan presentasi atau pencitraan diri dan pengungkapan diri merupakan manifestasi dari komunikasi interpersonal yang pada akhirnya mampu membuat dan membina sebuah hubungan menjadi semakin romantis.

Sehingga dapat disimpulkan bahwa sebuah hubungan interpersonal yang memiliki keromantisan akan tercipta melalui proses (1) pencitraan atau presentasi diri yang mampu menarik atensi orang lain; (2) Atensi yang dihasilkan dari pencitraan tersebut kemudian berubah menjadi sebuah hubungan pertemanan yang akrab melalui berbagai obrolan ringan; (3) sebuah hubungan pertemanan yang baik tersebut akan semakin menguat dan mengalami keintiman jika ditunjang oleh pengungkapan jati diri dan kepribadian seseorang.

Hal menarik yang ditemui pada salah satu jurnal yang masuk ke dalam ulasan penelitian ini adalah individu yang sedang berada di sebuah hubungan akan menjalani sebuah proses pengaturan batasan mengenai hal-hal yang dianggap pribadi atau privat atau yang boleh diketahui oleh orang lain. Penelitian yang dilakukan oleh Girly (2015) mengungkapkan bahwa wanita cenderung lebih transparan mengenai kisah cintanya dibandingkan dengan pria. Sedangkan keterbatasan komunikasi yang termediasi teknologi dalam membaca pesan non verbal menjadi alasan untuk membatasi diri dalam melakukan pengungkapan diri yang dikarenakan individu tersebut punya kecemasan akan pemaknaan pesan yang tidak sesuai dengan harapan. 
Pertemuan tatap muka dinilai menjadi jalan keluar untuk memudahkan individu dalam mengenal satu sama lain. Rahardaya dan Irwansyah (2021: 112) menjelaskan bahwa dalam komunikasi langsung (face to face), komunikator biasanya akan menyesuaikan lawan bicaranya baik dari nada bicara maupun maupun perilaku lawan bicara untuk mengakomodasi komunikan. Hal tidak dapat ditemui pada komunikasi online pengguna aplikasi seperti Tinder karena tidak ada fitur audio call / video call.

Jenis kelamin pada kenyataannya mempengaruhi bagaimana individu membangun hubungan pada tahap awal. Berdasarkan data yang diperoleh dari penelitian Schondienst dan Dang-Xuan (2011) terungkap bahwa pria cenderung langsung mendekati wanita pada online dating sedangkan wanita lebih mengandalkan isyarat halus. Hal menarik lainnya yang ditemukan dalam inisiasi memulai online dating pada penelitian Sharabi dan DeVette (2019) adalah munculnya kontak pertama dengan calon pasangan kencan, yang menggunakan tawaran percakapan yang cocok dengan jenis pick up lines atau kata kata gombal (lucu, langsung, tidak langsung) yang diidentifikasi dalam penelitian sebelumnya tentang pacaran tatap muka (Kleinke et al., 1986). Peserta juga mengungkapkan dan mencari informasi melalui strategi yang sebagian besar mencerminkan model tradisional pengembangan hubungan, termasuk pengungkapan tambahan (peripheral, menengah, dan inti; Altman \& Taylor, 1973) dan menyelesaikan ketidakpastian (Berger \& Calabrese, 1975).

Isi dari simpulan hendaknya berupa jawaban atas pertanyaan dan tujuan penelitian. Simpulan dipaparkan dalam satu paragraf, bukan poin-poin, dan diungkapkan bukan dalam kalimat statistik. Bila perlu, di bagian akhir kesimpulan dapat juga dituliskan hal-hal yang akan dilakukan terkait dengan gagasan selanjutnya dari penelitian tersebut.

\section{DAFTAR PUSTAKA}

Baym, N. K. Interpersonal life online. In S. Livingstone \& L. Lievrouw (Eds.), Handbook of new media: Social shaping and consequences of ICTs (pp. 62-76). (2002). London, England: Sage Publications.

Berger, C.R. \& Calabrese, R.J. Some Explorations In Initial Interaction And Beyond: Toward A Developmental Theory Of Interpersonal Communication. Human Communication Research, (1975), 1: 99-112. Doi:10.1111/J.1468-2958.1975.Tb00258.X

Bogdan, Robert and Steven Taylor. Introducing Qualitative Methods: Phenomenological. (1975). New York: A Wiley Interscience Publication.

Collins, N. L., \& Miller, L. C. Self-disclosure and liking: A meta-analytic review. Psychological Bulletin, (1994). 116, 457-475.

Dainton, Marianne dan Elaine D. Zelley.. Applying Communication Theory for Professional Life: A Practical Introduction. 4th Edition. (2018). Thousand Oaks: Sage Publications, Inc.

Derlega, V. J., Metts, S., Petronio, S., \& Margulis, S. T. Self-disclosure. (1993). Newbury Park, CA: Sage Publications.

Finkel, E. J., Eastwick, P. W., Karney, B. R., Reis, H. T., \& Sprecher, S. Online dating: A critical analysis from the perspective of psychological science. (1993). Psychological Science in the Public Interest, 13, 3-66. doi:10.1177/1529100612436552 
Fridha, M., \& Octavianti, M. Konstruksi Makna Kencan di Situs Pencarian Jodoh Tinder (Studi Fenomenologi pada Pria Pengguna Tinder di Jakarta). (2016). Jurnal Nomosleca, 2(2).

Goffman, Er. The Presentation of Self in Everyday Life. (1959). New York: Anchor Books.

Griffin, Em., Andrew Ledbetter., Glenn Grayson Sparks. A First Look at Communication Theory. (2018). McGraw-Hill Education: libgen.lc

Hadi S, I., Kurniawan, E., \& Irwansyah, I. Pengungkapan Diri di Situs Media Sosial Youtube. (2021). JURNAL LENSA MUTIARA KOMUNIKASI, 5(1), 42-51. https://doi.org/10.51544/jlmk.v5i1.1526

Jiang, L. C., Bazarova, N. N., \& Hancock, J. T. From perception to behavior: Disclosure Reciprocity and the intensification of intimacy in computer-mediated communication. (2013). Communication Research, 40, 125-143.

Joinson, A. N. Self-disclosure in computer-mediated communication: The role of selfawareness and visual anonymity. (2001). European Journal of Social Psychology

Joshi, Gunjan. Online dating-A motivated behaviour during pandemic. (2021). 10.5281/zenodo.4295667.

Kadarsih, Ristiana. Teori Penetrasi Sosial dan Hubungan Interpersonal. (2009). Jurnal Dakwah, Vol. 10, No. 1. Pp. 53 - 66. Yogyakarta: Universitas Islam Negeri (UIN).

Kurniati, Girly. Pengelolaan Hubungan Romantis Jarak Jauh: Studi Penetrasi Sosial Pasangan yang Terpisah Jarak Geografis. (2015). Jurnal Komunikasi Indonesia Vol. IV No.1 ISSN 2301-9816, vbb Sinta 2. Jakarta. Universitas Indonesia.

Littlejohn, S. W., Karen A Foss., John G Oetzel. Theory of Human Communication, Eleventh Edition. (2016). Illinois: Waveland Press.

Marston, Hannah \& Niles-Yokum, Kelly \& Earle, Sarah \& Gomez, Barbara \& Lee, David. OK Cupid, Stop Bumbling around and Match Me Tinder: Using Dating Apps Across the Life Course. (2020). Gerontology and Geriatric Medicine. 6. 233372142094749. $10.1177 / 2333721420947498$.

Merkle, E. R., \& Richardson, R. A. Digital dating and virtual relating: Conceptualizing computer mediated romantic relationships. (2000). Family Relations, 49, 187-192. doi:10.1111/j. 1741-3729.2000. 00187.x

Pennington, Natalie. Building and Maintaining Relationships in the Digital Age: Using Social Penetration Theory to Explore Communication through Social Networking Sites. (2015). Kansas: University of Kansas.

Peter, J., \& Valkenburg, P. M. Individual differences in perceptions of Internet communication. (2006). European Journal of Communication, 21, 213-226.

Prisbell, M., \& Andersen, J. F. The importance of perceived homophily, level of uncertainty, feeling good, safety, and self-disclosure in interpersonal relationships. (1980). Communication Quarterly, 28, 22-33.

Rahardaya, A., \& Irwansyah, I. Strategi Akomodasi Komunikasi dalam Proses Pembelajaran Secara Daring Selama Masa Pandemi Covid-19. (2021). JURNAL LENSA MUTIARA KOMUNIKASI, 5(1), 110-122. https://doi.org/10.51544/jlmk.v5i1.1662

Ramirez, A., Jr., \& Zhang, S. When online meets offline: The effect of modality switching on relational communication. Communication Monographs, (2007). 74, 287-310. doi:10.1080/036377507011543493 
Ruppel, E. K. Use of communication technologies in romantic relationships: Self-disclosure and the role of relationship development. (2015). Journal of Social and Personal Relationships, 32(5), 667-686.

Schoendienst, V., \& Dang-Xuan, L. The role of linguistic properties in online dating communication-A large-scale study of contact initiation messages. (2011). Proceedings of the 15th Pacific Asia Conference on Information Systems, 169, Brisbane, Australia.

Sespiani, K., Apilia, M., \& Irwansyah, I. (2021). Teori Reduksi Ketidakpastian dalam Cyber Romantic Relationship. JURNAL LENSA MUTIARA KOMUNIKASI, 5(1), 52-71. https://doi.org/10.51544/jlmk.v5i1.1599

Sharabi, L. L., \& Dykstra-DeVette, T. A. From first email to first date: Strategies for initiating relationships in online dating. (2019). Journal of Social and Personal Relationships, 36(11-12), 3389-3407.

Taylor, Dalmas A. The Development of Interpersonal Relationships: Social Penetration Processes. (1968). The Journal of Social Psychology, 75:1, 79-90. USA: Routledge.

Thurlow et. al. Computer Mediated Communication Social Interaction and The Internet. (2004). London: Sage Publication.

Tidwell, L. C., \& Walther, J. B. Computer-mediated communication effects on disclosure, impressions, and interpersonal evaluations: Getting to know one another a bit at a time. (2002). Human Communication Research, 28, 317-348. doi:10.1111/j.14682958.2002.tb00811.x

Tolstedt, B. E., \& Stokes, J. P. Self-disclosure, intimacy, and the depenetration process. (1984). Journal of Personality and Social Psychology, 46, 84-90. doi:10.1037/00223514.46.1.84

Ward, Janelle. Swiping, Matching, Chatting: Self-Presentation and Self-Disclosure on Mobile Dating Apps. (2016). Human IT, Vol. 13, no. 2, pp. 81 - 95. University of Borås.

West, R. \& Turner, L.H. Introducing Communication Theory, Third Edition. (2007). New York : McGraw-Hill.

Wotipka, C. D., \& High, A. C. An idealized self or the real me? Predicting attraction to online dating profiles using selective self-presentation and warranting. (2016). Communication Monographs, 83, 281-302. doi:10.1080/03637751.2016.1198041

Wahyudi, Eko. Kominfo Prediksi Penggunaan Internet Naik Terus Saat New Normal. (2020, Mei 28). Tempo.co. Retrived from https://bisnis.tempo.co/read/1347280/kominfoprediksi-penggunaan-internet-naik-terus-saat-new-normal/full\&view $=\mathrm{ok}$

Seidman, Elie. The Future of Dating, When 'online dating' is simply dating. (2020, July 18). TheJakartaPost.com https://www.thejakartapost.com/academia/2020/07/18/the-future-of-dating-whenonline-dating-is-simply-dating.html 